\title{
Abscisic Acid (ABA) mitigates drought stress in sunflower by enhancing water relations and osmotic adjustments
}

\author{
Safdar Hussain ${ }^{1}$, Shahid Farooq ${ }^{1}$, Muhammad Amjad Bashir ${ }^{2}$,
} Sagheer $\mathrm{Atta}^{2}$, Muhammad Jan ${ }^{3 *}$, Muhammad Mudassar Maqbool ${ }^{1}$, Arif Husain ${ }^{4}$ and Muhammad Naeem Mushtaq ${ }^{5}$

1. Department of Agronomy, Ghazi University, Dera Ghazi Khan-Pakistan

2. Department Plant Protection, Ghazi University, Dera Ghazi Khan-Pakistan

3. Barani Agricultural Research Institute (BARI), Chakwal-Pakistan

4. Department Soil \& Environmental Sciences, Ghazi University, Dera Ghazi Khan-Pakistan

5. University of Agriculture Faisalabad, Sub Campus Burewala-Pakistan

*Corresponding author's email: mjanleghari@gmail.com

Citation

Safdar Hussain, Shahid Farooq, Muhammad Amjad Bashir, Sagheer Atta, Muhammad Jan, Muhammad Mudassar Maqbool, Arif Husain and Muhammad Naeem Mushtaq. Abscisic Acid (ABA) mitigates drought stress in sunflower by enhancing water relations and osmotic adjustments. Pure and Applied Biology. Vol. 10, Issue 1, pp182-193. http://dx.doi.org/10.19045/bspab.2021.100019

\begin{tabular}{|c|c|c|c|}
\hline Received: 01/06/2020 & Revised: 24/08/2020 & Accepted: $25 / 08 / 2020$ & Online First: 16/09/2020 \\
\hline
\end{tabular}

\section{Abstract}

Drought stress significantly alters plant growth by disturbing plant water relations. Production and accumulation of compatible solutes improve plant water relations and help the plants to survive under water-limited conditions. Abscisic acid (ABA) could ameliorate the negative consequences of drought stress. Therefore, this two-year field study was conducted to infer the role ABA application $(0,5$ and $10 \mu \mathrm{M})$ at bud initiation (BBCH-51) and flower initiation (BBCH-55) in improving plant growth under water deficiency imposed at various growth stages. Drought stress was imposed at BBCH-51 and BBCH-55 by skipping irrigation, whereas a well-watered treatment was also included for comparison. The water relations, accumulation of compatible solutes and achene yield were significantly reduced by drought stress imposed at $\mathrm{BBCH}-51$ and $\mathrm{BBCH}-55$. The negative impacts of drought stress were more prominent at $\mathrm{BBCH}-55$ than $\mathrm{BBCH}-51$. Hence, $\mathrm{BBCH}-55$ proved more sensitive growth stage to drought stress than $\mathrm{BBCH}-51$. The ABA application under stress-free conditions significantly reduced achene yield, with more reduction with higher ABA level. The ABA application of $5 \mu \mathrm{M}$ either at BBCH-51 or BBCH-55 improved plant water relations, accumulation of compatible solutes and achene yield under drought stress whereas $10 \mu \mathrm{M}$ ABA application was less effective. Therefore, it is recommended that $5 \mu \mathrm{M}$ ABA application could ameliorate the negative impact of water deficit stress at BBCH-51 and $\mathrm{BBCH}-55$ in sunflower.

Keywords: ABA; Compatible solutes; Irrigation schedule; Water shortage

Introduction

Sunflower is an edible oilseed crop having short growing season, successfully grown under a range of water-limited environments globally [1-3]. It is a high yielding crop among edible oilseed crops; thus, could tighten up the production and consumption gap of edible oil in countries having huge edible oil import bill. Sunflower was introduced in Pakistan in 
1960s as an oilseed crop and now recognized as top source of edible oil after cotton seed [4].

The supply of irrigation water is decreasing globally due to decreasing capacity and the annual inflow of water reservoirs [5]. Water availability usually remains insufficient and inconsistent in arid and semiarid climates. Therefore, low availability of irrigation water is a major limiting factor to attain the maximum yield potential of the field crops under such climates. The most of the cultivated areas in Pakistan are categorized as arid or semiarid, which face increasing shortage of freshwater availability that would decrease by $32 \%$ in 2050 [6].

Water shortage during growing season exerts severe negative impacts effects on crop production. The severity of these negative impacts varies greatly depending on the susceptibility of different growth and developmental stages. Soil water deficit restricts plant establishment, growth and development, which consequently ends with decreased crop productivity [7]. Water use efficiency is low in arid and semiarid areas due to high application and conveyance losses. Therefore, water use efficiency should be improved in these regions by appropriate agronomic measures. The timing of irrigation can significantly improve the water use efficiency in these regions [8]. Water use efficiency could be increased by using deficit or regulated deficit irrigation to achieve higher crop yield [9]. The accumulation of compatible solutes, e.g., proline, glycinebetaine and soluble sugars can enhance the capacity of field crops to acclimatize to drought stress. These solutes are highly soluble and low in molecular weight. Even higher cytosolic concentrations of these compatible solutes are not toxic for plants [10]. Compatible solutes detoxify reactive oxygen species produced under water deficiency, enhance membrane stability and protect enzymatic and protein structure, which collectively help plants to avoid cellular dehydration.
Under water deficient conditions, lower osmotic potential results from accumulation of compatible solutes which help plants in attracting water molecules into the cells and eventually cell turgor is maintained to relatively normal level [11]. The ABA is a vital phytohormone in crop plants which is involved in abiotic stress tolerance. Similarly, reduced water availability due to drought stress triggers ABA biosynthesis in plant tissue [12]. The ABA is subsequently translocate to the guard cells, where it stimulates stomatal closure and ultimately improves the water relations of the plant through adaptive physiological expressions, including lowering transpiration and increasing influx of water into the roots. The ABA plays vital role during dormancy functions like germination, root architecture modulation, vegetative growth and seed development. Thus, ABA could ameliorate the negative consequences of water deficiency [13].

Several studies have reported that ABA improves plant water relations under drought stress and increases crop yield. The improvement in yield and plant water relations of sunflower by exogenously applied ABA has also been reported. However, there are limited reports on the role of different doses of ABA applied at $\mathrm{BBCH}-51$ and $\mathrm{BBCH}-55$ in improving plant water relations and yield. Therefore, this study was conducted to investigate the role of different doses of ABA in improving plant water relations and accumulation of compatible solutes under drought stress. Further, determining the sunflower growth stage which better responds to exogenous application of $\mathrm{ABA}$ was the other aim of the study.

\section{Materials and Methods \\ Description of experimental site and seed collection}

This two-year field study was conducted at Agronomic Research Farm, University of Agriculture, Faisalabad, Pakistan. The study area is characterized as semiarid [14]. The soil was sandy clay loam with 
64.3, 17.8 and $17.9 \%$ sand silt and clay, respectively. The $\mathrm{pH}$ and $\mathrm{EC}$ of the soil were 8.14 and $1.39 \mathrm{dS} \mathrm{m}^{-1}$, respectively. Similarly, the total organic matter, total nitrogen, available phosphorus and available potassium were, $0.58 \%, 0.59 \%$, $7.31 \mathrm{ppm}$ and $191 \mathrm{ppm}$, respectively. The meteorological data were obtained from the near weather station for the entire experimental period and presented in (Figure 1). The seeds of sunflower hybrid (Hysun-33) were obtained from Pakistan Oil Seed Development Board, Regional Office,

Faisalabad.

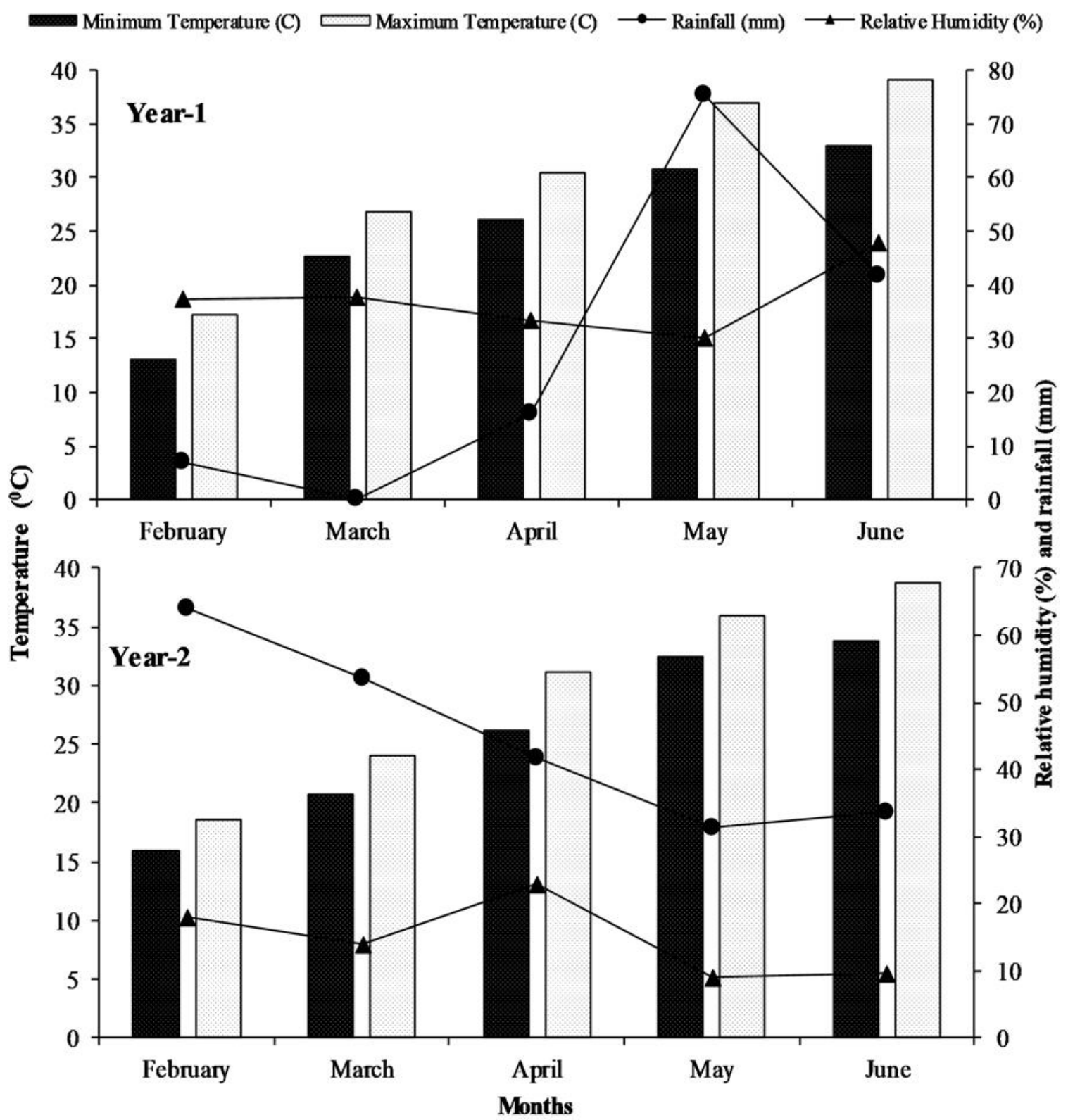

Figure 1. Meteorological data of the experimental site during experiment period

\section{Experimental treatments}

Drought stress was imposed at BBCH-51 (bud initiation) and $\mathrm{BBCH}-55$ (flower inititaiton) growth stages of sunflower by withholding irrigation (Table 1). A well- watered treatment where no irrigation was skipped was also included in the study. Similarly, ABA was applied at two different doses, (i.e., 5 and $10 \mu \mathrm{M}$ ) at the same groth stages where irrigation was 
skipped and no application of ABA was regarded as control. The experiment was laid out according to randomized complete block design with the factorial arrangement. Drought stress was the main factor, whereas ABA application was regarded as sub-factor. All treatments of the study had three replications and the experiment was repeated for two years.

\section{Crop husbandry}

Two cultivations, with tractor-mounted cultivator, followed by planking were applied to prepare seedbed suitable for plant growth. Seeds were planted on $3^{\text {rd }}$ week, i.e., $17^{\text {th }}$ and $12^{\text {th }}$ February during $1^{\text {st }}$ and $2^{\text {nd }}$ year of the study, respectively.
Seeds were sown on ridges with the help of dibbler by keeping seeds rate was kept $8 \mathrm{~kg}$ $\mathrm{ha}^{-1}$. Ridges-to-ridge and plant-to-plant distances were kept 75 and $25 \mathrm{~cm}$, respectively, which were maintained after thinning. Nitrogenous fertilizer as urea was applied at the rate of $150 \mathrm{~kg} \mathrm{~N} \mathrm{ha}^{-1}$ in two equal splits, i.e., just before sowing and with first irrigation. Phosphatic fertilizer was added in the soil just before the sowing at the rate of $100 \mathrm{~kg} \mathrm{P}_{2} \mathrm{O}_{5} \mathrm{ha}^{-1}$ as diammonium phosphate. Standard plant protection measures were applied to avoid any stress except described in the treatments.

Table 1. Details of the drought stress and exogenous ABA treatments

\begin{tabular}{|c|c|c|}
\hline Treatment & Code & Description \\
\hline \multirow{3}{*}{$\begin{array}{l}\text { Irrigation } \\
\text { Schedules } \\
\quad \text { (IS) }\end{array}$} & $\begin{array}{c}\text { IS }_{1111} \\
\text { (Control) }\end{array}$ & $\begin{array}{c}4 \text { irrigations [ } 1^{\text {st }} \text { irrigation at BBCH-16 }(5 \mathrm{DAS}), 2^{\text {nd }} \text { irrigation at } \\
\text { BBCH-51 (45 DAS), } 3^{\text {rd }} \text { irrigation at BBCH-55 (67 DAS), } 4^{\text {th }} \\
\text { irrigation at BBCH-71 (90 DAS)] }\end{array}$ \\
\hline & $\mathrm{IS}_{1011}$ & $2^{\text {nd }}$ irrigation skipped at $\mathrm{BBCH}-51$ \\
\hline & $\mathrm{IS}_{1101}$ & $3^{\text {rd }}$ irrigation skipped at $\mathrm{BBCH}-55$ \\
\hline \multirow{5}{*}{$\begin{array}{l}\text { Abscisic } \\
\text { acid } \\
\text { (ABA) }\end{array}$} & $\mathrm{ABA}_{0}$ & No application $(0 \mu \mathrm{M})$ of $\mathrm{ABA}$ \\
\hline & $\mathrm{ABA}_{5} \mathrm{BBCH}-51$ & $5 \mu \mathrm{M}$ exogenous application of $\mathrm{ABA}$ at $\mathrm{BBCH}-51$ \\
\hline & $\mathrm{ABA}_{5} \mathrm{BBCH}-55$ & $5 \mu \mathrm{M}$ exogenous application of ABA at BBCH-55 \\
\hline & $\mathrm{ABA}_{10} \mathrm{BBCH}-51$ & $10 \mu \mathrm{M}$ exogenous application of ABA at BBCH-51 \\
\hline & $\mathrm{ABA}_{10} \mathrm{BBCH}-55$ & $10 \mu \mathrm{M}$ exogenous application of ABA at BBCH-51 \\
\hline
\end{tabular}

$\mathrm{DAS}=$ days after sowing

\section{Determination of plant water relations}

Leaf water potential $\left(\Psi_{\mathrm{w}}\right)$ was determined between 8.00 to 10.00 am from two randomly selected plants in each treatment. The fully expanded youngest leaf ( $3^{\text {rd }}$ leaf, from the top) was used for $\Psi_{\mathrm{w}}$ measurements. The $\Psi_{\mathrm{w}}$ was measured with Scholander pressure chamber as described earlier [15]. The leaves used for $\Psi_{\mathrm{w}}$ measurements were immediately transported to lab and frozen (below -20 ${ }^{\circ} \mathrm{C}$ ) for seven days, which were latter thawed to extract cell sap using disposable syringe. Osmotic potential $\left(\Psi_{\mathrm{s}}\right)$ was directly determined from the extracted sap using an osmometer (Wescor-5500).

The difference between the values $\Psi_{\mathrm{s}}$ and $\Psi_{\mathrm{w}}$ was described at Turgor pressure $\left(\Psi_{\mathrm{p}}\right)$. $\Psi_{\mathrm{p}}=\Psi_{\mathrm{w}}-\Psi_{\mathrm{s}}$
Fresh weight (FW), turgid weight (TW) and dry weight (DW) of the collected leaf samples were measured as described earlier [16]. Relative water contents (RWC) of the leaves were calculated as below;

$$
\operatorname{RWC}(\%)=\frac{(\mathrm{FW}-\mathrm{DW})}{(\mathrm{TW}-\mathrm{DW})} \times 100
$$

\section{Compatible solutes content}

Leaf samples were collected 10 days after ABA application to determine the leaf proline (Pro) contents and total soluble sugars (TSS). Similarly, Pro was calculated following [17].

\section{Abscisic acid determination}

High-performance liquid chromatography [HPLC, Model 1C, A-Shimadzu Ltd. Japan, Detector SPD-6AV (Shimadzu)] was used to determine ABA concentration following [18]. 


\section{Statistical analysis}

Normality and homogeneity of variance in the collected data was tested first. Shapirowilk normality teste was used to assess the normality in the data and parameters with non-normal distribution were normalized by arcsine transformation technique. Homogeneity of variance was visually inspected by plotting the residuals before statistical analysis. The differences among the experimental years were tested by paired $t$ test, which indicated significant differences. Therefore, the data of both years were analyzed, presented and interpreted separately. One-way analysis of variance (ANOVA) was then used to test the significance in the data for control, drought stress at $\mathrm{BBCH}-51$ and drought stress at BBCH-55, separately. Least significance difference test at $5 \%$ probability was used to separate the treatment means where ANOVA indicated significant differences [19].

\section{Results and Discussion \\ Leaf water and osmotic potential (- MPa)}

Drought stress at BBCH-51 and BBCH-55 significantly influenced leaf water potential $\left(\Psi_{\mathrm{w}}\right)$ and osmotic potential $\left(\Psi_{\mathrm{s}}\right)$ of sunflower (Table 2). The ABA application under drought stress at at BBCH-51 and BBCH-55 variably affected $\Psi_{\mathrm{w}}$ and $\Psi_{\mathrm{s} \text {. Significant reduction in } \Psi_{\mathrm{w}} \text { and }}$ $\Psi_{\text {s }}$ was noted with ABA application at at BBCH-51 and BBCH-55 under wellwatered treatment of the study. ABA application to the plants exposed to water stress at BBCH-51 and BBCH-55 significantly increased $\Psi_{\mathrm{w}}$ and $\Psi_{\mathrm{s}}$ compared to the control. The lowest $\Psi_{\mathrm{w}}$ and $\Psi_{\mathrm{s}}$ were recorded under well-watered treatment, whereas the highest $\Psi_{\mathrm{w}}$ and $\Psi_{\mathrm{s}}$ were recorded for 5 and $10 \mu \mathrm{M}$ ABA application at BBCH-51 and BBCH-55 (Table 2). Similar trend of $\Psi_{w}$ and $\Psi_{\text {s }}$ was recorded at $\mathrm{BBCH}-51$ and $\mathrm{BBCH}-55$ in both years of the study.

Drought stress at BBCH-51 and BBCH-55 made the $\Psi_{\mathrm{w}}$ more negative, whereas ABA application ameliorated the negative impacts to significant extent. The $\Psi_{\mathrm{w}}$ was less negative with ABA application compared with no ABA application. The improvement in $\Psi_{\mathrm{w}}$ through ABA application served as a proxy of improved tolerance ending with moisture conservation. The ABA accumulation under water-limited environments enables the plants to partially close stomata [20, 21] which result in reduced transpiration; hence, moisture is conserved.

Drought stress either at BBCH-51 or BBCH-55 reduced $\Psi_{\mathrm{w}}$, which resulted in a parallel decrease in $\Psi_{s}$. The accumulation of solutes in plant cells linked to osmotic adjustments was responsible for decreased $\Psi_{\text {s }}[22,23]$. The $\Psi_{\text {s }}$ became less negative with ABA application in the current study. A higher reduction in $\Psi_{\mathrm{s}}$ was noted with ABA application at BBCH-51 compared with BBCH-55. The accumulation of compatible solutes e.g., GB, Pro, and TTS helped the plants to improve $\Psi_{\mathrm{s}}$ under drought stress. The accumulation of these solutes detoxify reactive oxygen species, stabilize membranes and enzymatic structures ultimately hinder dehydration [24-26].

\section{Leaf turgor pressure (MPa)}

Turgor pressure $\left(\Psi_{\mathrm{p}}\right)$ was significantly reduced by drought stress imposed at BBCH-51 and BBCH-55, and the reduction was higher under drought stress at BBCH-55 during both years of the study. Exogenous ABA application decreased $\Psi_{\mathrm{p}}$ under well-watered conditions, whereas improved $\Psi_{\mathrm{p}}$ under drought stress imposed at $\mathrm{BBCH}-51$ and BBCH-55 in each experimental year. The highest and the lowest $\Psi_{\mathrm{p}}$ under wellwatered conditions was recorded with no ABA application and $10 \mu \mathrm{M}$ ABA application at $\mathrm{BBCH}-55$, respectively (Table 2). Similarly, the highest and the lowest $\Psi_{\mathrm{p}}$ under drought stress at BBCH51 was noted with $5 \mu \mathrm{M}$ ABA application at BBCH-51 and no ABA application, respectively. Likewise, the highest and the lowest $\Psi_{\mathrm{p}}$ under drought stress at $\mathrm{BBCH}$ 55 was noted with $5 \mu \mathrm{M}$ ABA application 
at $\mathrm{BBCH}-55$ and no ABA application, respectively (Table 2).

Decreased $\Psi_{s}$ under droughty stress is regarded as major physiological adaptation for maintaining $\Psi_{\mathrm{p}}$. However, the activities of certain enzymes which cause starch breakdown and other substances resulting in negative $\Psi_{\mathrm{s}}$ are increased by $\mathrm{ABA}$ application. The $\Psi_{\mathbf{p}}$ was significantly decreased by drought stress at BBCH-51 and $\mathrm{BBCH}-55$. The reduced $\Psi_{\mathrm{p}}$ is directly related to decreased $\Psi_{\mathrm{w}}$ in the current study [26, 27]. The application of ABA significantly improved $\Psi_{\mathrm{p}}$, and the improvement was higher with $\mathrm{ABA}$ application at BBCH-51 compared with $\mathrm{BBCH}-55$. Conserved plant moisture due to stomatal closure was responsible for the improved $\Psi_{\mathrm{p}}[28,29]$.

Table 2. Interactive effect of irrigation schedules and exogenous application of ABA on water relations of sunflower

\begin{tabular}{|c|c|c|c|c|c|c|c|c|}
\hline & \multicolumn{2}{|c|}{ WP (-MPa) } & \multicolumn{2}{|c|}{ OP (-MPa) } & \multicolumn{2}{|c|}{ TP $(\mathrm{MPa})$} & \multicolumn{2}{|c|}{ RWC (\%) } \\
\hline Trea & $\overline{\text { Year } 1}$ & Year 2 & Year 1 & Year 2 & Year 1 & Year 2 & Year 1 & Year 2 \\
\hline \multicolumn{9}{|c|}{ No water stress $\left(\mathbf{I S}_{\mathbf{1 1 1 1}}\right)$} \\
\hline $\mathrm{ABA}_{0}$ & $586 a$ & $0.592 \mathrm{a}$ & $1.480 \mathrm{a}$ & $1.496 \mathrm{a}$ & $0.894 \mathrm{a}$ & $0.903 \mathrm{a}$ & $86.08 \mathrm{a}$ & $86.92 a$ \\
\hline $\mathrm{ABA}_{5} \mathrm{BBCH}-51$ & $525 b$ & $0.632 \mathrm{~b}$ & $1.507 \mathrm{~b}$ & $1.523 b$ & $0.882 \mathrm{ab}$ & $92 \mathrm{ab}$ & $85.68 \mathrm{a}$ & $85.95 \mathrm{ab}$ \\
\hline $\mathrm{ABA}_{5} \mathrm{BBC}$ & $555 b$ & & $1522 \mathrm{r}$ & & & & $4.93 \mathrm{~b}$ & $5.44 \mathrm{~b}$ \\
\hline $\begin{array}{c}\mathrm{ABA}_{10} \mathrm{BBCH}- \\
51 \\
\end{array}$ & $0.717 \mathrm{c}$ & $0.724 \mathrm{c}$ & $1.579 \mathrm{~d}$ & $1.596 \mathrm{~d}$ & $0.862 \mathrm{bc}$ & $0.871 b c$ & $83.27 \mathrm{c}$ & $84.32 \mathrm{c}$ \\
\hline $\begin{array}{r}\mathrm{ABA}_{10} \mathrm{I} \\
5\end{array}$ & $0.781 \mathrm{~d}$ & $0.789 \mathrm{~d}$ & $1.620 \mathrm{e}$ & $1.637 \mathrm{e}$ & $0.839 \mathrm{c}$ & $0.848 \mathrm{c}$ & $82.82 \mathrm{c}$ & $84.14 \mathrm{c}$ \\
\hline \multicolumn{9}{|c|}{ Water stress at BBCH-51 (IS $\left.\mathbf{I S 1 1}_{\mathbf{1 0 1}}\right)$} \\
\hline$\overline{\mathrm{A}_{0}}$ & $17 d$ & $1.128 \mathrm{~d}$ & $1.784 \mathrm{f}$ & $1.803 \mathrm{f}$ & $0.667 \mathrm{~d}$ & $0.674 d$ & $76.90 \mathrm{~d}$ & $77.39 \mathrm{c}$ \\
\hline $\mathrm{ABA}_{5} \mathrm{BBCH}$ & $815 a$ & $0.824 \mathrm{a}$ & $1.597 \mathrm{a}$ & $1.614 \mathrm{a}$ & $0.781 \mathrm{a}$ & $0.790 \mathrm{a}$ & $79.84 a$ & $80.92 a$ \\
\hline $\mathrm{ABA}$ & $917 b$ & & $1.668 \mathrm{~cd}$ & & $0.751 b c$ & & $78.11 b c$ & $77.91 \mathrm{c}$ \\
\hline $\begin{array}{r}\mathrm{ABA}_{10} \mathrm{E} \\
51\end{array}$ & $.848 \mathrm{a}$ & $0.857 \mathrm{a}$ & $1.619 \mathrm{~b}$ & $1.636 \mathrm{~b}$ & $0.771 \mathrm{ab}$ & 0.779ab & $78.69 b$ & $79.53 b$ \\
\hline $\begin{array}{r}\mathrm{ABA}_{10} \mathrm{E} \\
55\end{array}$ & 992 c & $1.002 \mathrm{c}$ & $1.719 \mathrm{e}$ & $1.737 \mathrm{e}$ & $0.727 \mathrm{c}$ & $0.735 c$ & $77.59 \mathrm{c}$ & $77.99 \mathrm{c}$ \\
\hline \multicolumn{9}{|c|}{ Water stress at BBCH-55 ( IS $\left._{1101}\right)$} \\
\hline$\overline{\mathrm{A}_{0}}$ & $327 \mathrm{e}$ & $1.341 \mathrm{e}$ & $1.881 \mathrm{~d}$ & $1.901 \mathrm{~d}$ & $0.554 \mathrm{e}$ & $0.560 \mathrm{e}$ & $73.85 c$ & $74.92 \mathrm{~d}$ \\
\hline 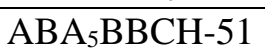 & $50 d$ & & $1.682 \mathrm{~b}$ & $1.700 \mathrm{~b}$ & $0.632 d$ & & $74.20 \mathrm{c}$ & $75.15 \mathrm{~cd}$ \\
\hline $\mathrm{ABA}_{5} \mathrm{I}$ & $392 a$ & & $1.626 \mathrm{a}$ & & $0.734 \mathrm{a}$ & & $5.85 \mathrm{a}$ & $77.02 \mathrm{ab}$ \\
\hline $\begin{array}{c}\mathrm{ABA}_{10} \mathrm{BBCH}- \\
51\end{array}$ & $0.982 b c$ & 0.9 & 1.6 & $1.691 \mathrm{bc}$ & 0.6 & $9 \mathrm{bc}$ & $8 \mathrm{~b}$ & $75.85 \mathrm{~cd}$ \\
\hline $\begin{array}{c}\mathrm{ABA}_{10} \mathrm{BBCH}- \\
55\end{array}$ & $0.953 \mathrm{D}$ & 0 . & 1.6 & 1. & $0.702 b$ & $9 \mathrm{~b}$ & $75.15 b$ & $76.05 b c$ \\
\hline LSD 0.05 & 0.0337 & 0.0341 & 0.0218 & 0.0220 & 0.0241 & 0.0253 & 0.634 & 0.975 \\
\hline
\end{tabular}

$\mathrm{ABA}=$ abscisic acid; $\mathrm{ABA} 0$, control (no ABA application); $\mathrm{AB}_{5} \mathrm{BBCH}-51=5 \mu \mathrm{M}$ exogenous application of $\mathrm{ABA}$ at $\mathrm{BBCH}-51 ; \mathrm{AB}_{5} \mathrm{BBCH}-55=5 \mu \mathrm{M}$ exogenous application of $\mathrm{ABA}$ at $\mathrm{BBCH}-55 ; \mathrm{AB}_{10} \mathrm{BBCH}-51=10$ $\mu \mathrm{M}$ exogenous application of $\mathrm{ABA}$ at $\mathrm{BBCH}-51 ; \mathrm{AB}_{10} \mathrm{BBCH}-55=10 \mu \mathrm{M}$ exogenous application of $\mathrm{ABA}$ at $\mathrm{BBCH}-55$; IS = irrigation schedule; LSD = least significant difference; $\mathrm{OP}=$ osmotic potential; $\mathrm{RWC}=$ relative water contents; $\mathrm{TP}=$ turgor pressure; $\mathrm{WP}=$ water potential. Means with different letters in a column significantly differ at $P<0.05$

\section{Leaf relative water contents $(\%)$}

Leaf relative water contents (RWC) were significantly influenced by drought stress imposed at $\mathrm{BBCH}-51$ and $\mathrm{BBCH}-55$ during both study years. Similarly, ABA application decreased the RWC under well- watered conditions, while improved RWC under drought stress in each year of the study. The highest and the lowest RWC under well-watered conditions were observed for no ABA application and $10 \mu \mathrm{M}$ 
ABA application at $\mathrm{BBCH}-51$ and $\mathrm{BBCH}-$ 55 , respectively (Table 2 ).

Similarly, the highest and the lowest RWC under drought stress imposed at BBCH-51 were recorded with $5 \mu \mathrm{M}$ ABA application at BBCH-51 and no application of ABA, respectively. In the same way, the highest and the lowest RWC under drought stress imposed at $\mathrm{BBCH}-55$ were recorded with 5 $\mu \mathrm{M}$ ABA application at BBCH-55 and no application of ABA, respectively (Table 2). Similar trend for all treatments was recorded during both experimental years.

The RWC were severely reduced under drought stress at BBCH-51 and BBCH-55. Earlier study has also reported that drought stress significantly reduced RWC of sunflower. The decrease in RWC was higher under drought stress at BBCH-55 compared to $\mathrm{BBCH}-51$. ABA application significantly improved RWC. The increases RWC are directly linked with moisture conservation by partial and gradual stomatal closure, deeper root penetration and accumulation of dehydrin protein. Similar findings have been reported in various earlier studies conducted on different plant species [29, 30]. Some contrasting reports also exist where $\mathrm{ABA}$ had no effect on RWC of maize plants subjected to drought stress [31].

\section{Compatible solutes}

Drought stress at $\mathrm{BBCH}-51$ and $\mathrm{BBCH}-55$ significantly altered the accumulation of compatible solutes, i.e., glycinebetaine (GB), leaf proline (Pro) and total soluble sugars (TSS) during both years of the study. Similarly, the accumulation of compatibles solutes was also influenced by different doses of ABA application at BBCH-51 and BBCH-55 (Table 3) during each study year. Overall, drought stress increased the accumulation of GB. The accumulation of GB was increased with ABA application under stress-free conditions, whereas decreased under drought stress. The highest and the lowest GB accumulation under stress-free conditions was recorded for 10 $\mu \mathrm{M}$ ABA application at $\mathrm{BBCH}-51$ and no ABA application, respectively. When drought stress was imposed at $\mathrm{BBCH}-51$ growth stage, the highest accumulation of GB was noted with no ABA application, whereas the lowest was recorded with $5 \mu \mathrm{M}$ $\mathrm{ABA}$ application at $\mathrm{BBCH}-51$. Likewise, the highest and the lowest GB accumulation under drought stress at $\mathrm{BBCH}-55$ growth stage was recorded for no ABA application and $5 \mu \mathrm{M}$ ABA application at $\mathrm{BBCH}-55$ (Table 3).

Like GB, the accumulation of Pro and TSS was increased under drought stress imposed at $\mathrm{BBCH}-51$ and $\mathrm{BBCH}-55$. The ABA application under stress-free conditions increased Pro and TSS accumulation, whereas decreased under drought stress. The highest and the lowest Pro and TSS accumulation under stress-free conditions was recorded for $10 \mu \mathrm{M}$ ABA application at BBCH-51 and no ABA application, respectively. Similarly, the highest Pro and TSS accumulation under drought at $\mathrm{BBCH}-$ 51 growth stage was noted with no ABA application, whereas the lowest was recorded with $5 \mu \mathrm{M}$ ABA application at BBCH-51. Likewise, the highest and the lowest Pro and TSS accumulation under drought stress at $\mathrm{BBCH}-55$ was recorded for no ABA application and $5 \mu \mathrm{M}$ ABA application at BBCH-55 (Table 3). Similar trend was recorded for both study years.

The endogenous ABA accumulation was increased under drought stress. Exogenous ABA application increased endogenous ABA accumulation under stress-free conditions as well as under drought stress. The highest and the lowest accumulation of endogenous $\mathrm{ABA}$ under drought stress imposed at BBCH-51 was noted with $10 \mu \mathrm{M}$ $\mathrm{ABA}$ application at $\mathrm{BBCH}-51$ and no $\mathrm{ABA}$ application, respectively. Likewise, the highest and the lowest endogenous $\mathrm{ABA}$ accumulation under drought stress at $\mathrm{BBCH}$ 55 was recorded for $10 \mu \mathrm{M}$ ABA application at BBCH-55 and no ABA application, respectively (Table 3 ). Similar trend was recorded for both study years.

The accumulation of compatible solutes such as GB, Pro and TSS are considered as the most important mechanism of drought tolerance [30]. Drought stress resulted in significant production of GB in current study and higher GB was accumulated under drought stress at BBCH-55. The GB helps the plants to maintain $\Psi_{\mathrm{p}}$ under adverse 
environmental conditions, particularly drought stress [32, 33]. Moreover, GB protects enzymes, functional proteins, lipids and sustained electron flow through thylakoid membrane $[34,35]$ all of which collectively result in improved drought tolerance. The higher accumulation of GB in plants is considered as a sign of high drought tolerance ability. The ABA application improved GB accumulation which helped the plants to cope drought stress through improved moisture availability. Partial stomatal closure and deeper root proliferation are responsible for improved moisture [36, 37].

The TSS play a significant role in osmoregulation under drought stress. The accumulation of TSS was increased under drought stress and higher amounts of TSS were accumulated under drought stress at BBCH-55 compared to BBCH-51. The breakdown of polysaccharides was responsible for higher TSS accumulation, which ultimately helped in osmotic adjustment [38, 39].

Drought stress significantly increased Pro accumulation with higher amount accumulated under drought stress at $\mathrm{BBCH}-$ 51. The Pro biosynthesis increases when $\Psi_{\mathrm{w}}$ is low. As a result of which reduced Pro oxidation occurs in mitochondria which increases leaf Pro concentration [40-42]. The ABA application lowered Pro accumulation compared with no ABA application which can be linked with the exogenous ABA application [41]. Stomatal closure and conserved moisture due to ABA application might also be responsible for reduced Pro accumulation [43].

The endogenous ABA contents were increased under drought stress and higher increase was noted under drought stress at BBCH-55. The ABA-mediated stomatal regulation was responsible for improved endogenous ABA contents [44-47]. The ABA application did not affect endogenous ABA contents under stress-free conditions [48] has reported similar findings earlier, and highlighted that leaf ABA content may remained half of the applied ABA, however, leaf size and volume of sap extracted for ABA concentration analysis potentially have significant influence. The application of ABA at higher doses results in higher endogenous $\mathrm{ABA}$ contents which improved metabolism [49] and decreased endogenous ABA concentration [50].

Achene yield ( $\left.\mathrm{kg} \mathrm{ha}^{-1}\right)$

Achene yield was significantly reduced by drought stress, and reduction was severe when drought was imposed at BBCH-55. The exogenous application of ABA decreased the achene yield under wellwatered conditions compared to no application of ABA. However, achene yield was improved under drought stress at BBCH-51 and BBCH-55 with ABA application compared with no ABA application (Table 3). The highest and the lowest achene yield under stress-free conditions was recorded for no ABA application and $5 \mu \mathrm{M}$ ABA application at BBCH-55, respectively. When drought stress was imposed at BBCH-51, the highest achene yield was noted with $5 \mu \mathrm{M}$ ABA application at BBCH-51, whereas the lowest was recorded with $10 \mu \mathrm{M}$ ABA application at $\mathrm{BBCH}-55$. Likewise, the highest and the lowest achene yield was recorded with $5 \mu \mathrm{M}$ ABA application at BBCH-55, whereas the lowest was recorded with $10 \mu \mathrm{M}$ ABA application at BBCH-51 (Table 3).

Drought stress significantly hampered the achene yield; however, ABA application helped to improve achene yield to significant extent. The reduction in achene yield was higher under drought stress at $\mathrm{BBCH}-55$ compared to $\mathrm{BBCH}-51$. The reduction in achene yield can be directly linked with disturbed plant water relations and growth. The ABA-mediated yield improvement can be explained with improved plant water relations and osmotic adjustments in the current study. The higher reduction in achene yield at $\mathrm{BBCH}-55$ might be linked with pollen abortion as flowers were initiating at this stage. The application of 5 $\mu \mathrm{M}$ ABA either at $\mathrm{BBCH}-51$ or $\mathrm{BBCH}-55$ improved the achene yield compared with no application. However, higher dose, i.e., 10 $\mu \mathrm{M}$ lowered achene yield compared to control indicating that it might be toxic for plants. 
Table 3. Interactive effects of irrigation schedules and exogenous application of ABA on compatible solutes, ABA contents in leaf and achene yield of sunflower

\begin{tabular}{|c|c|c|c|c|c|c|c|c|c|c|}
\hline \multirow[b]{2}{*}{ Treatments } & \multicolumn{2}{|c|}{ 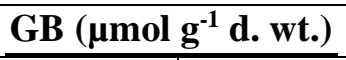 } & \multicolumn{2}{|c|}{ Pro $\left(\mu \mathrm{mol} \mathrm{g}{ }^{-1}\right.$ f. wt. $)$} & \multicolumn{2}{|c|}{ TSS (mg g g. $^{-1}$ wt.) } & \multicolumn{2}{|c|}{ 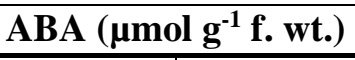 } & \multicolumn{2}{|c|}{ Achene yield $\left(\mathrm{kg} \mathrm{ha}^{-1}\right)$} \\
\hline & Year 1 & Year 2 & Year 1 & Year 2 & Year 1 & Year 2 & Year 1 & Year 2 & Year 1 & Year 2 \\
\hline \multicolumn{11}{|c|}{ No water stress $\left(\mathbf{I S}_{\mathbf{1 1 1}}\right)$} \\
\hline $\mathrm{ABA}_{0}$ & $12.03 \mathrm{c}$ & $9.23 \mathrm{~d}$ & $4.14 d$ & $4.08 \mathrm{~d}$ & $72.33 \mathrm{e}$ & $70.22 \mathrm{e}$ & $0.13 \mathrm{a}$ & $0.12 b$ & $2809.40 \mathrm{a}$ & $3015.18 \mathrm{a}$ \\
\hline $\mathrm{ABA}_{5} \mathrm{BBCH}-51$ & $12.56 \mathrm{~b}$ & $10.29 b$ & $4.72 b$ & $4.66 \mathrm{~b}$ & $79.39 \mathrm{~b}$ & $78.26 \mathrm{~b}$ & $0.14 \mathrm{a}$ & $0.13 \mathrm{ab}$ & $2717.45 b$ & $2888.53 b$ \\
\hline $\mathrm{ABA}_{5} \mathrm{BBCH}-55$ & $11.69 \mathrm{c}$ & $9.45 \mathrm{~d}$ & $4.47 \mathrm{c}$ & $4.40 \mathrm{c}$ & $75.14 d$ & $73.64 d$ & $0.14 \mathrm{a}$ & $0.13 \mathrm{ab}$ & $2645.85 \mathrm{bc}$ & $2724.59 \mathrm{~cd}$ \\
\hline $\mathrm{ABA}_{10} \mathrm{BBCH}-51$ & $12.95 \mathrm{a}$ & $10.7 \mathrm{a}$ & $4.92 \mathrm{a}$ & $4.83 \mathrm{a}$ & $82.49 \mathrm{a}$ & $80.52 \mathrm{a}$ & $0.14 \mathrm{a}$ & $0.14 \mathrm{a}$ & $2589.15 \mathrm{c}$ & $2777.74 \mathrm{c}$ \\
\hline $\mathrm{ABA}_{10} \mathrm{BBCH}-55$ & $11.88 \mathrm{c}$ & $9.8 \mathrm{c}$ & $4.64 b c$ & $4.58 \mathrm{bc}$ & $77.29 \mathrm{c}$ & $75.55 \mathrm{c}$ & $0.15 \mathrm{a}$ & $0.14 \mathrm{a}$ & $2479.64 d$ & $2640.76 \mathrm{~d}$ \\
\hline \multicolumn{11}{|c|}{ Water stress at BBCH-51 ( IS $\left._{1011}\right)$} \\
\hline $\mathrm{ABA}_{0}$ & $17.81 \mathrm{a}$ & $15.36 \mathrm{a}$ & $7.08 \mathrm{a}$ & $7.00 \mathrm{a}$ & $90.11 \mathrm{ab}$ & $89.22 \mathrm{a}$ & $0.73 \mathrm{e}$ & $0.67 \mathrm{e}$ & $1942.23 c$ & 2094.71c \\
\hline $\mathrm{ABA}_{5} \mathrm{BBCH}-51$ & $14.74 \mathrm{f}$ & $12.68 \mathrm{e}$ & $5.46 \mathrm{e}$ & $5.39 \mathrm{e}$ & $84.16 \mathrm{e}$ & $83.75 \mathrm{~d}$ & $1.54 \mathrm{~b}$ & $1.41 \mathrm{~b}$ & $2451.94 \mathrm{a}$ & $2630.92 \mathrm{a}$ \\
\hline $\mathrm{ABA}_{5} \mathrm{BBCH}-55$ & $15.26 \mathrm{e}$ & $13.16 \mathrm{~d}$ & $5.98 \mathrm{~d}$ & $5.90 \mathrm{~d}$ & $86.82 \mathrm{~d}$ & $85.56 \mathrm{c}$ & $0.87 \mathrm{~d}$ & $0.79 \mathrm{~d}$ & $1837.91 \mathrm{~d}$ & 1983.36d \\
\hline $\mathrm{ABA}_{10} \mathrm{BBCH}-51$ & $15.88 \mathrm{~d}$ & $13.95 \mathrm{c}$ & $6.45 \mathrm{c}$ & $6.35 \mathrm{c}$ & $87.91 \mathrm{c}$ & $86.13 \mathrm{c}$ & $1.82 \mathrm{a}$ & $1.67 \mathrm{a}$ & $2205.19 b$ & $2357.42 b$ \\
\hline $\mathrm{ABA}_{10} \mathrm{BBCH}-55$ & $16.75 \mathrm{bc}$ & $14.66 \mathrm{~b}$ & $6.73 b$ & $6.63 \mathrm{~b}$ & $89.12 b$ & $88.31 \mathrm{~b}$ & $0.94 \mathrm{c}$ & $0.86 \mathrm{c}$ & $1536.79 \mathrm{e}$ & $1665.28 \mathrm{e}$ \\
\hline \multicolumn{11}{|c|}{ Water stress at BBCH-55 $\left(\mathbf{I S}_{\mathbf{1 1 0 1}}\right)$} \\
\hline $\mathrm{ABA}_{0}$ & $18.24 \mathrm{a}$ & $16.64 \mathrm{a}$ & $6.93 a$ & $6.85 \mathrm{a}$ & $93.21 \mathrm{a}$ & $92.21 \mathrm{a}$ & $0.78 \mathrm{e}$ & $0.72 \mathrm{e}$ & $1860.72 \mathrm{c}$ & $1906.39 \mathrm{c}$ \\
\hline $\mathrm{ABA}_{5} \mathrm{BBCH}-51$ & $17.50 \mathrm{~b}$ & $15.95 b$ & $6.01 \mathrm{c}$ & $5.89 \mathrm{~cd}$ & $91.88 \mathrm{bc}$ & $90.19 \mathrm{~b}$ & $1.35 \mathrm{~d}$ & $1.24 \mathrm{~d}$ & $1763.59 \mathrm{~d}$ & $1785.51 \mathrm{~d}$ \\
\hline $\mathrm{ABA}_{5} \mathrm{BBCH}-55$ & $16.59 \mathrm{~d}$ & $14.76 \mathrm{~d}$ & $5.25 \mathrm{e}$ & $5.16 \mathrm{f}$ & $87.92 \mathrm{e}$ & $87.17 \mathrm{~d}$ & $1.98 \mathrm{~b}$ & $1.82 \mathrm{~b}$ & $2448.79 \mathrm{a}$ & $2518.82 \mathrm{a}$ \\
\hline $\mathrm{ABA}_{10} \mathrm{BBCH}-51$ & $17.85 \mathrm{~b}$ & $16.07 \mathrm{~b}$ & $6.59 \mathrm{~b}$ & $6.49 \mathrm{~b}$ & $92.66 \mathrm{ab}$ & $91.78 \mathrm{a}$ & $1.77 \mathrm{c}$ & $1.62 \mathrm{c}$ & $1394.14 \mathrm{e}$ & $1487.21 \mathrm{e}$ \\
\hline $\mathrm{ABA}_{10} \mathrm{BBCH}-55$ & $16.98 \mathrm{c}$ & $15.16 \mathrm{c}$ & $5.80 \mathrm{~d}$ & $5.72 \mathrm{e}$ & $90.95 \mathrm{~cd}$ & $89.15 \mathrm{c}$ & $2.48 \mathrm{a}$ & $2.28 \mathrm{a}$ & $2044.45 b$ & $2068.63 b$ \\
\hline LSD 0.05 & 0.392 & 0.347 & 0.174 & 0.177 & 1.072 & 0.825 & 0.023 & 0.016 & 91.856 & 95.572 \\
\hline
\end{tabular}

$\mathrm{ABA}=$ abscisic acid; $\mathrm{ABA0}$, control (no ABA application); $\mathrm{AB}_{5} \mathrm{BBCH}-51=5 \mu \mathrm{M}$ exogenous application of $\mathrm{ABA}$ at $\mathrm{BBCH}-51 ; \mathrm{AB} 5 \mathrm{BBCH}-55=5 \mu \mathrm{M}$ exogenous application of $\mathrm{ABA}$ at $\mathrm{BBCH}-55 ; \mathrm{AB}_{10} \mathrm{BBCH}-51=10 \mu \mathrm{M}$ exogenous application of $\mathrm{ABA}$ at $\mathrm{BBCH}-51 ; \mathrm{AB}_{10} \mathrm{BBCH}-55=10 \mu \mathrm{M}$ exogenous application of $\mathrm{ABA}$ at $\mathrm{BBCH}-$ 55; IS = irrigation schedule; LSD = least significant difference; $\mathrm{GB}=$ glycinebetaine; $\mathrm{ns}=$ non-significant; Pro = proline; TSS = total soluble sugars. Means with different letters in a column significantly differ at $P<0.05$ 


\section{Conclusion}

Sunflower water relations, accumulation of compatible solutes and achene yield were significantly reduced by drought stress imposed at BBCH-51 and $\mathrm{BBCH}-55$. The negative impacts of drought stress were more prominent at $\mathrm{BBCH}-55$ than $\mathrm{BBCH}-51$. Hence, BBCH-55 proved more sensitive growth stage to drought stress than BBCH-51. The ABA application under stress-free conditions significantly reduced achene yield, with more reduction with higher ABA level. The ABA application of $5 \mu \mathrm{M}$ either at $\mathrm{BBCH}-51$ or $\mathrm{BBCH}-55$ improved plant water relations, accumulation of compatible solutes and achene yield under drought stress whereas $10 \mu \mathrm{M}$ ABA application was less effective. Therefore, it is recommended that $5 \mu \mathrm{M}$ ABA application could ameliorate the adverse impacts of drought stress at $\mathrm{BBCH}-51$ and BBCH-55.

\section{Authors' contributions}

Conceived and designed the experiments: $S$ Hussain, S Farooq \& MA Bashir, Performed the experiments: S Hussain \& M Jan, Analyzed the data: S Atta \& MM Maqbool, Contributed reagents/ materials/ analysis tools: A Husain \& MN Mushtaq, Wrote the paper: S Hussain \& M Jan.

\section{Acknowledgement}

Authors acknowledge financial support of Higher Education Commision (HEC) of Pakistan to conduct this study.

\section{References}

1. Agboma PC, Sinclair TR, Jokinen K, Peltonen-Sainio P \& Pehu E (1997). An evaluation of the effect of exogenous glycinebetaine on the growth and yield of soybean: timing of application, watering regimes and cultivars. Field Crops Res 54: 51-64.

2. Ahmad PCA, Jaleel M, Salem A, Nabi G \& Sharma S (2010). Roles of enzymatic and nonenzymatic antioxidants in plants during abiotic stress. Crit Rev Biotechnol 30: 161-175.

3. Allakhverdiev SI, Hayashi H, Nishiyama Y, Ivanov AG, Aliev JA \& Carpentier R (2003). Glycinebetaine protects the D1/D2/Cytb559 complex of photosystem II against photo-induced and heat-induced inactivation. J Plant Physiol 160: 41-49.

4. Alves AAC \& Setter TL (2004). Abscisic acid accumulation and osmotic adjustment in cassava under water deficit. Environ Exp Bot 51: 259-271.

5. Amin A, Nasim W, Mubeen M, Sarwar S, Urich P, Ahmad A, Wajid A \& Ali QS (2018). Regional climate assessment of precipitation and temperature in Southern Punjab (Pakistan) using SimCLIM climate model for different temporal scales. Theoretical Appl Climat 131: 121131.

6. Bates LS, Waldren RP \& Teare ID (1973). Rapid determination of free proline for water-stress studies. Plant Soil 39: 205-207.

7. Blum A (2017). Osmotic adjustment is a prime drought stress adaptive engine in support of plant production. Plant, Cell Environ 40: 4-10.

8. Borel C \& Simonneau T (2002). Is the ABA concentration in the sap collected by pressurizing leaves relevant for analysing drought effects on stomata? Evidence from ABA-fed leaves of transgenic plants with modified capacities to synthesize ABA. J Exp Bot 53: 287296.

9. Borovskii GB, Stupnikova IV, Antipina AI, Vladimirova SV \& Voinikov VK (2002). Accumulation of dehydrin-like proteins in the mitochondria of cereals in response to cold, freezing, drought and ABA treatment. BMC Plant Biol 2: 5.

10. Chai Q, Gan Y, Zhao C \& Siddique HKM (2016). Regulated deficit irrigation for crop production under drought stress. A review. Agron Sustain Develop 36: 3.

11. Demir AO, Göksoy AT, Büyükcangaz $\mathrm{H}$, Turan ZM \& Köksal ES (2006). Deficit irrigation of sunflower (Helianthus annuus L.) in a sub-humid climate. Irrig Sci 24: 279-289.

12. Sah SK, Reddy KR and Li J (2016). Abscisic Acid \& Abiotic Stress Tolerance in Crop Plants. Front Plant Sci 7: 571.

13. Duque LO \& Setter TL (2013). Cassava Response to Water Deficit in Deep Pots: Root and Shoot Growth, ABA, and Carbohydrate Reserves in Stems, Leaves and Storage Roots. Tropic. Plant Biol 6: 199-209.

14. Farooq $\mathrm{M}$, Gogoi $\mathrm{N}$, Barthakur $\mathrm{N}$, Baroowa B, Bharadwaj N, Alghamdi SS \& Siddique HKM (2017). Drought Stress in Grain Legumes during Reproduction 
and Grain Filling. J Agron Crop Sci 203: 81-102.

15. Fujita Y, Fujita M, Shinozaki K \&Yamaguchi SK (2011). ABA-mediated transcriptional regulation in response to osmotic stress in plants. J Plant Res 124 : 509-525.

16. Grassini P, Hall AJ \& Mercau JL (2009). Benchmarking sunflower water productivity in semiarid environments. Field Crops Res 110: 251-262.

17. Hussain M, Farooq S, Hasan W, Ul-Allah S, Tanveer M, Farooq M \& Nawaz A (2018). Drought stress in sunflower: Physiological effects and its management through breeding and agronomic alternatives. Agric Water Manag 201: 152-166.

18. Hussain S, Ali A, Ibrahim M, Saleem M \& Bukhsh MA (2012). Exogenous application of abscisic acid for drought tolerance in sunflower (Helianthus annuus L.): a review. J Animal Plant Sci 22: 806-826.

19. Hussain S, Ma BL, Saleem MF, Anjum SA, Saeed A \& Iqbal J (2012). Abscisic acid spray on sunflower acts differently under drought and irrigation conditions. Agron J 104: 561-568.

20. Hussain S, Saleem M, Ashraf M, Cheema M \& Haq M (2010). Abscisic acid, a stress hormone helps in improving water relations and yield of sunflower (Helianthus annuus L.) hybrids under drought. Pak J Bot 42: 2177-2189.

21. Kaur M, Gupta AK \& Zhawar VR (2014). Antioxidant response and Lea genes expression under exogenous $\mathrm{ABA}$ and water deficit stress in wheat cultivars contrasting in drought tolerance. $J$ Plant Biochem Biotechnol 23: 18-30.

22. Khaliq T, Hussain N, Ali A, Ullah A, Ahmad M \& Ahmad A (2015). Quantification of root-shoot development and water use efficiency in autumn maize (Zea mays L.) under different irrigation strategies. J Environ Agric Sci 6: 16-22.

23. Khazaei Z \& Estaji A (2020). Effect of foliar application of ascorbic acid on sweet pepper (Capsicum annuum) plants under drought stress. Acta Physiol Plantarum 42(7): 1-12.

24. Kurepin LV, Ivanov AG, Zaman M, Pharis RP, Allakhverdiev SI, Hurry V \& Hüner NPA (2015). Stress-related hormones and glycinebetaine interplay in protection of photosynthesis under abiotic stress conditions. Photosyn Res 126: 221235.

25. Manzoor H, Athar HUR, Rasul S, Kanwal T, Anjam MS, Qureshi MK \& Ashraf M (2016). Avenues for improving drought tolerance in crops by ABA regulation. Water Stress and Crop Plants. John Wiley \& Sons, Ltd, pp. 177-193.

26. Meng Q, Chen X, Lobell DB, Cui Z, Zhang Y, Yang H \& Zhang F (2016). Growing sensitivity of maize to water scarcity under climate change. Sci Rep 6: 19605.

27. Mirza MMQ \& Ahmad QK (2005). Climate change and water resources in South Asia. CRC Press.

28. Mohammadi M, Pouryousef M, Tavakoli A \& Fard EM (2019). Improvement in photosynthesis, seed yield and protein content of common bean (Phaseolus vulgaris) by foliar application of 24epibrassinolide under drought stress. Crop and Pasture Sci 70(6): 535545.

29. Nasim W, Ahmad A, Ahmad S, Nadeem M, Masood M, Shahid M \& Fahad S (2017). Response of sunflower hybrids to nitrogen application grown under different agro-environments. $J$ Plant Nutr 40: 82-92.

30. Nawaz U, Shahid S, Ahmad R, Ibrahim MU, Wajid A, Manan A \& Qureshi MI (2016). Indus Basin Irrigation System and climatic trends regarding glacial regimes and water runoff. $J$ Environ Agric Sci 9: 28-36.

31. Nawaz M \& Wang $Z$ (2020). Abscisic Acid and Glycine Betaine Mediated Tolerance Mechanisms under Drought Stress and Recovery in Axonopus compressus: A New Insight. Sci Rep 10(1): 1-10.

32. Salem A, Omar A \& Ali M (2013). Various responses of sunflower genotypes to water stress on newly reclaimed sandy soil. Acta Agron Hung 61: 55-69.

33. Samarah NH (2016). Understanding How Plants Respond to Drought Stress at the Molecular and Whole Plant Levels. In: Hossain, M.A., S. H. Wani, S. Bhattacharjee, D. J. Burritt and L. S. P. Tran (Eds.), Drought Stress Tolerance in 
Plants, Vol 2: Molecular and Genetic Perspectives. Springer International Publishing, Cham, pp. 1-37.

34. Savi T, Casolo V, Luglio J, Bertuzzi S, Trifilo P, Lo MA \& Nardini A (2016). Species-specific reversal of stem xylem embolism after a prolonged drought correlates to endpoint concentration of soluble sugars. Plant Physiol. Biochem. 106: 198-207.

35. Schachtman DP \& Goodger JQD (2008). Chemical root to shoot signaling under drought. Trends Plant Sci. 13: 281-287.

36. Sedaghat M, Sarvestani ZT, Emam Y, Bidgoli AM \& Sorooshzadeh A (2020). Foliar-Applied GR24 and Salicylic Acid Enhanced Wheat Drought Tolerance. Russian J Plant Physiol 67(4): 733-739.

37. Serraj R \& Sinclair TR (2002). Osmolyte accumulation: can it really help increase crop yield under drought conditions. Plant, Cell Environ 25: 333-341.

38. Shah NA, Shah H and Akmal N (2005). Sunflower area and production variability in Pakistan: opportunities and constraints. Helia 28: 165-178.

39. Shahzad MA, Jan SU, Afzal F, Khalid M, Gul A, Sharma I, Sofo I \& Ahmad P (2016). Drought stress and morphophysiological responses in plants. Water Stress and Crop Plants. John Wiley \& Sons, Ltd, pp. 452-467.

40. Shao HB, Chu LY, Jaleel CA and Zhao CX (2008). Water-deficit stress-induced anatomical changes in higher plants. Curr Res Biol 331: 215-225.

41. Singh S, Tripathi DK, Dubey NK and Chauhan DK (2016). Global explicit profiling of water deficit-induced diminutions in agricultural crop sustainability. Water Stress and Crop Plants. John Wiley \& Sons, Ltd, pp. 5874.
42. Tayyab N, Naz R, Yasmin H, Nosheen A, Keyani R, Sajjad M \& Roberts TH (2020). Combined seed and foliar pretreatments with exogenous methyl jasmonate and salicylic acid mitigate drought-induced stress in maize. Plos One 15(5): 232-239.

43. Steel R, Torrie J \& Dickey D (1997). Principles and procedures of statistics: a biometrical approach. McGraw-Hill, New York, NY, USA.

44. Tezara W, Mitchell VJ, Driscoll SD \& Lawlor DW (1999). Water stress inhibits plant photosynthesis by decreasing coupling factor and ATP. Nat 401: 914917.

45. Tolk JA \& Howell TA (2012). Sunflower water productivity in four Great Plains soils. Field Crops Res 127: 120-128.

46. Ünyayar S, Kelep Y and Ünal E (2004). Proline and ABA levels in two sunflower genotypes subjected to water stress. Bulg J Plant Physiol 30: 34-47.

47. Wang R, Gao M, Ji S, Wang S, Meng Y \& Zhou Z (2016). Carbon allocation, osmotic adjustment, antioxidant capacity and growth in cotton under long-term soil drought during flowering and bollforming period. Plant Physiol Biochem 107: 137-146.

48. Wilkinson S \& Davies WJ (2002). ABAbased chemical signalling: the coordination of responses to stress in plants. Plant, Cell Environ 25: 195-210.

49. Wojtyla $Ł$, Lechowska K, Kubala S \& Garnczarska M (2016). Molecular processes induced in primed seedsincreasing the potential to stabilize crop yields under drought conditions. J Plant Physiol 203: 116-126.

50. Zhang J \& Davies WJ (1990). Does ABA in the Xylem Control the Rate of Leaf Growth in Soil-Dried Maize and Sunflower Plants. J Exp Bot 41: 11251132. 